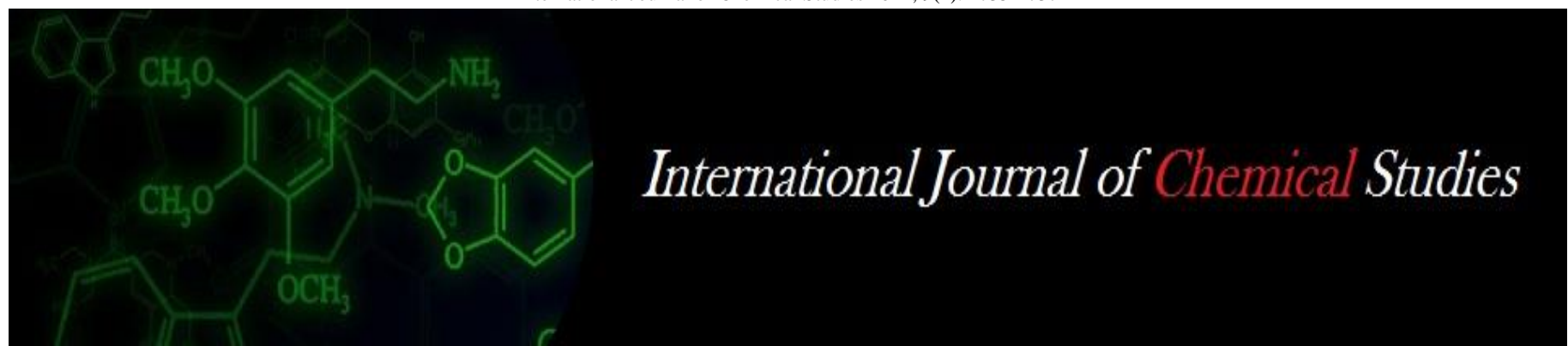

P-ISSN: 2349-8528

E-ISSN: 2321-4902

www.chemijournal.com

IJCS 2021; 9(1): 1735-1737

(C) 2021 IJCS

Received: 04-10-2020

Accepted: 11-11-2020

\section{Dalvi AA}

Department of Agricultural

Botany, Vasantrao Naik

Marathwada Krishi Vidyapeeth,

Parbhani, Maharashtra, India

\section{SV Kalyankar}

Department of Agricultural

Botany, Vasantrao Naik

Marathwada Krishi Vidyapeeth,

Parbhani, Maharashtra, India

RA Gaikwad

Department of Agricultural

Botany, Vasantrao Naik

Marathwada Krishi Vidyapeeth,

Parbhani, Maharashtra, India

\section{PS Rathod}

Department of Agricultural Botany, Vasantrao Naik

Marathwada Krishi Vidyapeeth,

Parbhani, Maharashtra, India
Corresponding Author:

Dalvi AA

Department of Agricultural Botany, Vasantrao Naik

Marathwada Krishi Vidyapeeth,

Parbhani, Maharashtra, India

\section{Effect of bioagent and seed coating on seed quality parameters in soybean (Glycine max (L.) Merrill.)}

\author{
Dalvi AA, SV Kalyankar, RA Gaikwad and PS Rathod
}

DOI: https://doi.org/10.22271/chemi.2021.v9.i1y.11475

\begin{abstract}
A field experiment entitled "Effect of bioagent and seed coating on yield and seed quality parameters in soybean (Glycine max L.) Mirril.) was conducted during kharif 2019 at experimental field of Department of Agriculture Botany, Vasantrao Naik Marathwada Agriculture University, Parbhani. Seed of soybean var. MAUS 162 were coated with polymer in combination with different bioagents and maintained untreated seed (control). After seed treatment, the seed were sown in the field with three replication and seven treatment adopting randomized block design in order to find out the effect of seed treatments on various seed quality parameters. Oil content, protein content, Germination percentage, seedling length, and vigour index were significantly superior in treatment $\mathrm{T}_{7}$ : $\mathrm{T}_{2}+$ Biomix@6 $6 \mathrm{ml}$ followed by $\mathrm{T}_{4} \mathrm{~T}_{2}+$ Rhizobium japonicum @6ml than all other seed coating treatments over the control in the soybean var MAUS -162.
\end{abstract}

Keywords: Soybean, seed coating, bio-agents, polymer and seed quality

\section{Introduction}

Soybean (Glycine max L.) is the wonder crop of the $20^{\text {th }}$ Century, which is commonly referred as 'miracle crop 'golden bean' or gold from soil which belonging to family Leguminosae, sub family Papilionaceae and the genus Glycine L. It is supposed to have originated in China and was introduced to India in 1968 (Bragg cv.) from USA (Nagata, 1970). It is basically a pulse crop and gained the importance as an oil seed crop. Soybean has the unique significance on this age of energy crisis and has a vital role in agriculture, enterprise and export change of India. The $30 \%$ of global vegetable oil and $60 \%$ of vegetable protein is derived from soybean. Due to high protein content, soybean is known as 'poor man's meat'. Recently the area under soybean in our country is increasing year after year due to certain advantages like short duration crop, less pest and disease attack but productivity is not considerably increased and has remained almost stagnant for the past several years. There are numerous reasons for low productivity such as low seed germination poor storability, which low vigour and poor seed quality, lack of use of growth regulators, Micronutrients, biofertilizers and bio fungicides.

Seed coating an effective technique to seed enhancement, in particular for large seeded agronomic and horticultural plants and its major benefit is that the seed enhancement material is placed directly on to the seed. Seed coating material is extremely thin, which permits multiple layers on the seed with 1 to $10 \%$ increase in seed weight. The film coat enhances, flow ability of the seed, dust free, safe to handle and has bright colour and quality appearance. Seed coating materials were reported to improve the germination and increase the seedling emergence at changing soil moisture regime mainly in the sub-optimal range (Scott., 1989; Sherin and Susan John., 2003) ${ }^{[11]}$. Application of chemical fungicide has been replaced by biocontrol agents because of emergence of fungicide resistant. In view of the above circumstances, the present investigation was undertaken to study the effect of bioagent and seed coating on seed quality parameters in soybean.

\section{Material and Methods}

A field experiment entitled "Effect of bioagent and seed coating on yield and seed quality parameters in soybean (Glycine max L.) Mirril.) Was conducted during kharif 2019 at experimental field of Department of Agriculture Botany, Vasantrao Naik Marathwada 
Agriculture University, Parbhani. The experiment was laid out in randomized block design with three replication and seven treatments. The seed were coated with polymer in combination with different bioagents and maintained untreated seed (control). The seed treatments are $\mathrm{T}_{1}$ : Untreated seed, $\mathrm{T}_{2}$ : Polymer coating@ 3ml/kg, $\mathrm{T}_{3}$ : $\mathrm{T}_{2}+$ Tricoderma viride @ $5 \mathrm{ml}, \mathrm{T}_{4}: \mathrm{T}_{2}+$ Rhizobium japonicum @6ml, $\mathrm{T}_{5}: \mathrm{T}_{2}+$ Phosphorus solubilizing bacteria@6ml, $\mathrm{T}_{6}$ : $\mathrm{T}_{2}+$ Potash Solubilizing bacteria@6ml, $\mathrm{T}_{7}$ : $\mathrm{T}_{2}+$ Biomix@6ml. Seed of soybean var. MAUS 162 were coated with polymer in combination with different bioagents and maintained untreated seed (control). The data were collected on various characters. Oil content in percentage was determined by soxlet method, Percentage of oil content was analysed in the sample and observations were recorded for each plot in each replication. Protein content in seed was estimated by using KEL PLUS Nitrogen Estimation System. Standerd germination test was conducted by rolled towel paper method as described in the ISTA rules of seed testing (ISTA 1993). After harvesting, the seed were subjected to germination percentage, vigour index test based on seedling length along with control. Seedling length was measured and mean seedling length was expressed in centimeters. Coated seed are compared with uncoated seed for their quality parameters viz., oil content, protein content, germination percentage, seedling length and seedling vigour index. Seedling vigour index was calculated as per formula given by ISTA (1976).

Seedling Vigour Index $=$ Germination percentage $(\%)$ x Mean seedling length $(\mathrm{cm})$

\section{Result and Discussion \\ Oil content \\ Seed Oil Content (\%)}

Oil content in percentage is presented in the table 1 which was found to be significant. Higher oil content was recorded by treatment $\mathrm{T}_{7}-\mathrm{T}_{2}+$ Biomix@6ml/Kg of seed $(19.23 \%)$, followed by treatment $\mathrm{T}_{4}: \mathrm{T}_{2}+$ Rhizobium japonicum@6ml/kg of seed $(19.06 \%)$ and Lowest oil content was recorded by $\mathrm{T}_{1}$ : Control seed $(18.30 \%)$. The mean oil content in seed differed significantly due to application of seed coating which could be due to increased accumulation of hexose sugars at the time of synthesis of triacylglycerol.

\section{Seed Protein Content (\%)}

The protein content in seed shows significant effect due to seed coating treatments. Protein content in percentage is presented in the table 1 which was found to be significant.
Higher protein content was recorded by treatment $\mathrm{T}_{7}: \mathrm{T}_{2}+$ Biomix@6ml/Kg of seed $(40.83 \%)$ followed by $\mathrm{T}_{4}: \mathrm{T}_{2}+$ Rhizobium japonicum@6ml/kg of seed (39.70\%) and Lowest protein content was recorded by $\mathrm{T}_{1}$ :Control seed seed (38.73).

\section{Seed Germination ( $\%)$}

Data on germination percentage as influenced by seed different bioagent are recorded in Table 1. All treatment have higher germination percentage than control. Treatment $\mathrm{T}_{7}: \mathrm{T}_{2}$ + Biomix@6ml/Kg of seed recorded the (92.00\%) followed by treatment $\mathrm{T}_{4}: \mathrm{T}_{2}+$ Rhizobium japonicum @6 $6 \mathrm{ml} / \mathrm{kg}$ of seed (91.00) was recorded significantly higher germination percentage and minimum in $\mathrm{T}_{1}$ : control $(88.00 \%)$. The increase in germination percentage might be due to the hydrophilic nature of the polymer that has increased the imbibition rate which led to faster activation of cells and resulted in enhancement of mitochondrial activity leading to the formation of more high energy compounds and vital bio molecules, which were made available during the early phase of germination and reduced imbibitional damage by regulating the water uptake. These findings are in agreement with those of earlier researchers in soybean (Imran Baig, 2005) ${ }^{[6]}$.

\section{Seedling length $(\mathbf{c m})$}

Seedling length includes shoot length and root length together. Data revealed that there is significant difference in seeding length among the treatments which is presented in Table 1. It is evident from the data that seed coating treatment has effect on seedling length which is presented in Table 15. All the treatments recorded to be significant with respect to seedling length. The treatment $\mathrm{T}_{7}$ : $\mathrm{T}_{2}+$ Biomix @6ml/Kg of seed recorded maximum seedling shoot length $(28.13 \mathrm{~cm})$ followed by $\mathrm{T}_{4}$ : $\mathrm{T}_{2}+$ Rhizobium japonicum@6ml $/ \mathrm{kg}$ of seed (27.60) and $\mathrm{T}_{3}: \mathrm{T}_{2}+$ Trichoderma viride@5ml $/ \mathrm{Kg}$ of seed (26.73). Data ranges from $24.46\left(\mathrm{~T}_{1}\right)$ to $28.13\left(\mathrm{~T}_{7}\right)$. This increase in total seedling length may be due to increase in shoot length and root length.

\section{Vigour index}

Seedling vigour index is the most important aspect of seed quality as it decides the vigour level or performance of a seed. Vigour index is presented in table 1. All the seed coating treatments have the significant effect on vigour index. Highest vigour index was recorded by treatment T7- $\mathrm{T}_{2}+$ Biomix@6ml/Kg of seed (2588) followed by seed coating with $\mathrm{T}_{4}: \mathrm{T}_{2}+$ Rhizobium japonicum @6 $\mathrm{ml} / \mathrm{kg}$ of seed (2511) and minimum with $\mathrm{T}_{1}$ : Control $\mathrm{T} 1(2152)$.

Table 1: Effect of seed coating on Oil content (\%), Protein content (\%), Germination (\%), Seedling length and Vigour index

\begin{tabular}{|c|c|c|c|c|c|}
\hline Treatments & Oil content (\%) & Protein content (\%) & Germination (\%) & Seedling length & Vigour index \\
\hline $\mathrm{T}_{1}$ (Untreated seeds) & 18.30 & 38.73 & 88.00 & 25.88 & 2277 \\
\hline $\mathrm{T}_{2}$ Polycot @ 3ml/Kg of seed & 18.36 & 39.23 & 88.81 & 26.11 & 2263 \\
\hline $\mathrm{T}_{3}: \mathrm{T}_{2}+$ Trichoderma viride @ 5ml/Kg of seed & 19.00 & 39.63 & 90.33 & 27.15 & 2452 \\
\hline $\mathrm{T}_{4}: \mathrm{T}_{2}+$ Rhizobium japonicum @6 6ml/kg of seed & 19.06 & 39.70 & 91.00 & 28.06 & 2554 \\
\hline $\mathrm{T}_{5}: \mathrm{T}_{2}+$ Phosphorus solubilizing bacteria @ 6ml/kg & 18.70 & 39.40 & 89.00 & 27.08 & 2401 \\
\hline $\mathrm{T}_{6}: \mathrm{T}_{2}+$ Potash solubilizing bacteria @6ml/of seed) & 18.63 & 39.33 & 90.33 & 26.48 & 2393 \\
\hline $\mathrm{T}_{7}: \mathrm{T}_{2}+$ Biomix @6ml/Kg of seed & 19.23 & 40.83 & 92.00 & 28.08 & 2583 \\
\hline S.E(m) \pm & 0.12 & 0.17 & 0.63 & 0.32 & 125.33 \\
\hline CD at 5\% & 0.37 & 0.55 & 1.98 & 1.02 & 40.22 \\
\hline
\end{tabular}

\section{Conclusion}

From the above result it is concluded that seed quality parameters viz., oil content, protein content, germination percentage, seedling length and seedling vigour index were significantly increased due to seed coating with $\mathrm{T}_{7}\left(\mathrm{~T}_{2}+\right.$ Biomix@6ml/Kg of seed) and $\mathrm{T}_{4}$ : (Rhizobium japonicum@6ml/kg of seed in soybean var MAUS -162. 


\section{References}

1. Chachalis D, Smith ML. Hydrophobic polymer application reduces imbibition rate and partially improves germination or emergence of soybean seedlings. Seed Science and Technology 2001;29(1):91-98.

2. Dadlani M, Shenoy VV, Seshu V. Seed coating to improve plant stand establishment in rice. Seed Science and Technology 1992;20:307-313.

3. Mukhtar I, Hannan A, Atiq M, Nawaz A. Impact of Trichoderma species on Seed Germination in Soybean Pak. J Phytopathol 2012;24(2):159-162.

4. Jeong YO, Cho JL. Effect of coating materials and priming on seed germination of tomato and pepper. $\mathbf{J}$ Korean soc. Hort Sci 1995;36(2):185-191.

5. Jitendra Kumar, Nsar K, Arun Kumlt MB, Suresh Wall, Siiakil NA, Rajendra Prasad et al. Development of polymeric seed coats for seed quality enhancement of soybean. Indian Journal of Agricultural Sciences 2007;77(11):738-43.

6. Kunkur V, Hunje R, Biradar Patil NK, Vyakarnhal BS. Effect of seed coating with polymer, fungicide and insecticide on seed quality in cotton during storage. Karnataka journal of agricultural sciences 20071;20(1):137-139.

7. Mona MM, Ragab KA, Abada Maisa L, Abd-El-Moneim, Yosra Z Abo-Shosha. Effect of different mixtures of some bioagents and Rhizobium phaseoli on bean damping-off under field condition. International Journal of Scientific \& Engineering Research 6(7):2229-5518.

8. Monalisa SP, Beura JK, Tarai RK, Naik M. Seed quality enhancement through biopriming in common bean (Phaseolus vulgaris. L). J Appl. and Nat. Sci 2017;9(3):1740-1743.

9. Qusemi Sayed Tayef, Dr. Prashant Kumar Rai. Effect of priming with Trichoderma and rhizobium on germination, vigor and viability of maize (Zia mays L) seeds. Int. J of Multidisci. Res. and Devel 2016;3(8):0407.

10. Renugadevi J, Natarajan N, Srimathi P. Influence of film coating with polycot on Seed quality characteristics of cluster bean. Madras Agricultural Journal 2008:95:475479.

11. Sherin Susan john, Bharathi A, Natesan, Raja K. Effect of Polymer Coating on Germination and Seedling Vigour in Maize cv. Co 1 Karnataka J Agric. Sci 2005;18(2):343-348.

12. Struve TH, Hopper WT. The effect of polymer film coating on cotton seed imbibition, EC, germination and emergence. Proceeding Beltwide Cotton conference, Nashville, TN, USA 1996;12(2):1167-1170.

13. Taylor AG, Allen PS, Bennett MA, Bradford KJ, Burrisand JS, Misra MK. Seed enhancements. Seed Sci Res 1998;8:245-56.

14. Shelar VR, Shaikh RS, Nikam AS. Soybean Seed Quality During Storage Agric. Rev 2008;29(2):125-131.

15. Vijay Kumar K, Hunje R, Biradar Patil NK, Vyakarnhal BS. Effect of seed coating with polymer, fungicide and insecticide on seed quality in cotton during storage. Karnataka journal of Agricultural Sciences 2007;20(1):137-139.

16. Wasule DL, Wadyalkar SR, Buldeo AN. Effect of phosphate solubilizing bacteria role of Rhizobium on nodulation by soybean. First International Meeting on Microbial Phosphate 2007;102:139-142. 